\title{
Quantitative Economic Analysis of the Industrial Structure of Coastal City of Shandong Province
}

\author{
Lei She Ping, Ma Hui
}

school of humanity, economics and law Northwestern Polytechnical University No.127, youyi west road ,Xi'an, Shaanxi, China

\begin{abstract}
Based on shift-share method, the author analyses the industrial structure benefit of coastal city of Shandong since 1990. Results indicate that the industrial structure of coastal city of Shandong is not rational in different degree, which results in slow-moving of the economic growth. The industrial structure of Yantai, weihai, rizhao are in lower level, in particular tertiary industry, so it cannot provide much-needed supporting services for rapid development of the second industry. The proportion of the first industry in the economy is extremely large in rizhao, it can't adapt to the new period of industrial structure development trend. Therefore, continual adjustment, optimization of the economic structure and improvement of the industrial quality are needed so as to promote the coordinated and rapid development of economy.
\end{abstract}

Index Terms: Shift-share method; industry structure; uantitative economic analysis

(C) 2012 Published by MECS Publisher. Selection and/or peer review under responsibility of the Research Association of Modern Education and Computer Science.

\section{Introduction}

Industrial structure and economic growth has a very close relationship, the industrial structure is the basis of economic growth. Different industrial structure has different overall efficiency, which can lead to economic growth at different rates. Different speed of economic growth have different demands to the industrial structure and can promote industrial structure change. From the progress of industrial development in developed countries, GDP in the three industries is developed in the following patterns( the proportion is from the biggest to the smallest):" the second industry-the first industry-the third industry" to "the second industry-the third industry-the first industry" to "the third industry-the second industry-the first industry".

And the industry structure of coastal city in Shandong has its own different economic contribution to the development on Shandong Province. The paper analyzes the future situation of the industrial structure and its

* Corresponding author.

E-mail address: leimansh@163.com, lize1221@163.com 
competition ability of coastal cities within Shandong province by employing the deviation method (shift-share the mathematical model, the method).

\section{Shift-share theory}

Shift-share analysis is one of the widely used techniques for examining regional growth and comparisons. The shift-share model decomposes economic change in a region into three additive components: the reference area component, the industry mix and the regional share. The decomposed variable may be income, capital stock, employment, value added, or a variety of other measurements[1].

The reference area component generally refers to the national economy and is called the national share (NS), which measures the regional target variable change if it grew at the same rate as the nation. Capital stock is used as the target variable in this paper. The industrial mix (IM) is the industry composition of the region and refers to the capital stock change due to the difference between the growth rate of a particular sector and that of the whole national industry. Thus it reflects the degree to which the region specializes in sectors that are fast or slow growing nationally[2]. The regional share (RS) reflects the regional impact on a particular sector, which is measured by the capital stock change due to the difference between the regional growth rate and the national growth rate of the industry. The total shift (TS) is the sum of the three components, reflecting the changing economic position of the region relative to the nation.

\section{Mathematical models}

Suppose after the period of $[0, t]$, economic gross and structure of region $i$ have changed. Suppose the gross economic scale of region $i$ at the beginning stage (the base year) is bio, and that at the final stage is bit. Meanwhile, according to certain rules, divide the regional economy into industrial sections $\cdot$ bijo and bijt are the economic scales of section $\mathrm{j}$ at the beginning and the final stages respectively; Bo and $\mathrm{Bt}$ are the gross economic scale of region $\mathrm{i}$ at the beginning and final stages in corresponding time; Bjo and Bjt are the economic scales of section $\mathrm{j}$ of region $\mathrm{i}$ at the beginning and final stages[].

The diversification rate of section $\mathrm{j}$ in region $\mathrm{i}$ during $[\mathrm{o}, \mathrm{t}]$ is $(1)$ :

rij=(bijt-bij0)/bijo $\quad(j=1,2,3 \cdots n)$.

The diversification rate of section $\mathrm{j}$ in the whole country during $[0, \mathrm{t}]$ is (2):

$R j=($ Bjt-Bjo $) /$ Bjo $\quad(j=1,2,3 \cdots n)$.

Standardize the scale of each industrial section in region $i$, as in (3).

bij=bio*Bjo/Bo.

Thus during[o,t], Gij,the increase of section $\mathrm{j}$ can be divided into three components : quotient component $\mathrm{Nij}$, structure deviatoric component Pij and competition deviatoric component Dij, which are expressed in (4)-(8) :

$$
\begin{aligned}
& G i j=N i j+P i j+D i j . \\
& N i j=b i j * R j . \\
& P i j=(b i j o-b i j) * R j . \\
& D i j=b i j *(r i j-R j) . \\
& G i=N i+P i+D i .
\end{aligned}
$$


Table 1 Result of shift-share method of Shandong

(Unit: 100 million )

\begin{tabular}{|c|c|c|c|c|c|c|c|c|c|c|c|c|c|c|c|}
\hline & \multicolumn{3}{|c|}{ Shandong } & \multicolumn{3}{|c|}{ Qingdao } & \multicolumn{3}{|c|}{ Yantai } & \multicolumn{3}{|c|}{ Weihai } & \multicolumn{3}{|c|}{ Rizhao } \\
\hline & $\begin{array}{c}\text { quotient } \\
\text { compon } \\
\text { ent } N\end{array}$ & $\begin{array}{c}\text { structure } \\
\text { deviatori } \\
\mathrm{c} \\
\text { compone } \\
\text { nt P }\end{array}$ & $\begin{array}{c}\text { competiti } \\
\text { on } \\
\text { deviatori } \\
\text { c } \\
\text { compone } \\
\text { nt D }\end{array}$ & $\begin{array}{c}\text { quotient } \\
\text { compone } \\
\text { nt } \mathrm{N}\end{array}$ & $\begin{array}{l}\text { structu } \\
\text { re } \\
\text { deviato } \\
\text { ric } \\
\text { compo } \\
\text { nent P }\end{array}$ & $\begin{array}{c}\text { compet } \\
\text { ition } \\
\text { deviato } \\
\text { ric } \\
\text { compo } \\
\text { nent D }\end{array}$ & $\begin{array}{c}\text { quotient } \\
\text { compone } \\
\text { nt N }\end{array}$ & $\begin{array}{c}\text { structure } \\
\text { deviatori } \\
\text { c } \\
\text { compone } \\
\text { nt P }\end{array}$ & \begin{tabular}{|c} 
compet \\
ition \\
deviato \\
ric \\
compo \\
nent D
\end{tabular} & $\begin{array}{c}\text { quotient } \\
\text { compone } \\
\text { nt } \mathrm{N}\end{array}$ & \begin{tabular}{|c} 
structu \\
re \\
deviato \\
ric \\
compo \\
nent P
\end{tabular} & $\begin{array}{c}\text { competitio } \\
\text { n deviatoric } \\
\text { component } \\
\text { D }\end{array}$ & $\begin{array}{c}\text { quotie } \\
\text { nt } \\
\text { compo } \\
\text { nent N }\end{array}$ & $\begin{array}{c}\text { structure } \\
\text { deviatori } \\
\mathrm{c} \\
\text { compone } \\
\text { nt P }\end{array}$ & \begin{tabular}{|l} 
compet \\
ition \\
deviato \\
ric \\
compo \\
nent D
\end{tabular} \\
\hline $\begin{array}{c}199 \\
0- \\
199 \\
5\end{array}$ & 3410.16 & -11.81 & 47.91 & 411.75 & 15.27 & 32.14 & 338.32 & -6.16 & 59.28 & 164.03 & -10.52 & 126.18 & 73.94 & -10.64 & 28.81 \\
\hline $\begin{array}{c}199 \\
5- \\
200 \\
0\end{array}$ & 3130.45 & -21.71 & 267.09 & 431.41 & 9.68 & 111.01 & 368.52 & -10.25 & -13.28 & 217.89 & -14.16 & 36.55 & 78.19 & -9.31 & 34.95 \\
\hline $\begin{array}{c}200 \\
0- \\
200 \\
5\end{array}$ & 7059.16 & 2 & 2958.89 & 1454.42 & 1.61 & 19.79 & 1073.92 & 14.18 & 45.96 & 665.92 & 4.7 & -46.72 & 255.8 & -21.61 & -15.23 \\
\hline $\begin{array}{c}200 \\
5- \\
200 \\
8\end{array}$ & $\begin{array}{c}11870.3 \\
5\end{array}$ & 100.45 & 756.2 & 1827.87 & 29.77 & $\begin{array}{c}- \\
157.66\end{array}$ & 1364.53 & -0.25 & 51.34 & 793.15 & -1.5 & -179.77 & 289.18 & -1.56 & 83.53 \\
\hline $\begin{array}{c}190 \\
0- \\
200 \\
8\end{array}$ & $\begin{array}{c}22828.5 \\
3\end{array}$ & -230.31 & 6926.38 & 3536.1 & 236.81 & 474.41 & 2905.44 & -85.46 & 495.52 & 1408.63 & $\begin{array}{c} \\
144.92\end{array}$ & 694.95 & 634.96 & -162.06 & 490.42 \\
\hline
\end{tabular}

Source: China city statistical yearbook, 1991-2009

Among the above, Nij is quotient component (or the average increase effect of the region), which reflects the generated changes according to the average increase impact of the region with the standardized industrial sections. Pij is structure deviatoric component (or the industrial structure effect), which reflects the impact and contribution of section structure to economical development. Dij is the competition deviatoric component, which reflects the comparative competitive ability of regional sections - The greater the value of the Dij is, the greater the impact of section competitiveness on the economic development - According to the above theory, the general increase of $\mathrm{Gi}$ of a region can be expressed in (9):

$G i=N i+P i+D i$.

\section{Data Analysis and the Results}

\section{A. Data resource}

The paper deals with the data of four coastal cities from 1990 to 2008[4-8], and generation the corresponding data into the above model respectively. Then we get the each city's deviatoric component. The result are as show in table 1 and table 2.

\section{B. Analysis}

According to the table 1 and table 2, the following conclusions can be drawn.

Firstly, in different period, except for QingDao,the value of structural deviation component in the coastal cities in ShanDong, are all negative in YanTai and WeiHai with only five years of positive value from 2000 to 2005, which shows the superior economic growth in Qingdao. The 5 phases of RiZhao are all negative, indicating that the three times adjustment of industrial has severe contribution to the wholly economic growth. 
Besides, in different period, the economic growth of QingDao is inferior to Yantai, Weihai, but superior to Rizhao during 2000 to 2005, demonstrating the three times effective adjustment of industrial has contribute lot to the economic growth.

Thirdly, the influence on the regional economic growth of the geographic conditions or industrial competitiveness can be reflected from the analysis on the competitive deviation component. To be specific, the value of competitive deviation component for QingDao from 2005 to 2008, YanTai from 1995 to 2000, WeiHai from 2000 to 2008, and RiZhao 2000 to 2005 are all negative showing the needs to strengthen the adjustment of industrial structure, especially in the third industry in these cities. In other research phase, the value of competitive deviation component for most coastal cities are positive, indicating the great impact on total amount of the economic.

Next, from the year of 2005 to 2008, the result of structural industry is positive, with negative value of competitive deviation component, showing the influence of industrial structure adjustment which is not competitive. Specifically speaking, the value of structural industry from 1990 to 1995 for YanTai, WeiHai, and RiZhao, 1995 to 2000 for WeiHai, and RiZhao, 2005 to 2008 for YanTai ,and RiZhao, are all negative with positive competitive deviation component. It proves that the economical growth are outpaced by factors besides

structural industry, and competitiveness are the key. During the research, both the value for the structural industry and competitive deviation component for YanTai 1995 to 2000 , WeiHai 2005 to 2008, and RiZhao 2000 to 2005 is not advantageous. The weak technological foundation, slow pace of development, unreasonable in industrial structure all restrain the progress of economical development.

Lastly, get to the industry structure in detail. The industry structures of economic growth for Qingdao are mainly in accordance with the " the third industry-the first industry-the second industry " rule while the industry trend of competitiveness tends to be " the third industry-the second industry-the first industry ", indicating that the industrial structure is more reasonable. The industry structure for Yantai develops from the mode of" the first industry-the second industry-the third industry," to "the second industry-the first industry-the third industry " while the development trend of competitive follows the module " the second industry-the third industry-the first industry ", demonstrating the unreasonable industry structure which needs to be adjusted. Situation of industry structures of economic growth contributing to economical development in Weihai abides by and changes from the model "the first industry-the second industry-the third industry," to " the first industry-the third industry-the second industry " to "the second industry-the third industry-the first industry", while the law of competitive development is in accordance with the " the third industry-the second industry-the first industry " to " the second industry-the third industry-the first industry " and to " the third industry-the first industry-the second industry," the law of development, indicating the unreasonable industrial structure.

\section{Conclusions}

In conclusion, to achieve further development, the four coastal cities must take counter measures on the basis of their concrete conditions.

Firstly, coordinating urban and rural economic development to enhance the harmony development of advantage industry as the breakthrough point. Through the government guidance, preferential policy, intensive input, to promote the strategic adjustment of agricultural structure, develop the primary industry, strengthen the agricultural industrialization, realize polymerization of economy of the agricultural production, improve the efficiency of agricultural production, and achieve the realization of marketization of the agricultural production, supply and sale. 
Table 2 Result of industrial detail of Shandong coastal city

(Unit: 100 million )

\begin{tabular}{|c|c|c|c|c|c|c|c|c|c|c|c|c|c|}
\hline & \multicolumn{3}{|c|}{ Qingdao } & \multicolumn{3}{|c|}{ Yantai } & \multicolumn{3}{|c|}{ Weihai } & \multicolumn{3}{|c|}{ Rizhao } \\
\hline & & $\begin{array}{l}\text { prima } \\
\text { ry } \\
\text { indus } \\
\text { try }\end{array}$ & $\begin{array}{l}\text { Second } \\
\text { ary } \\
\text { industry }\end{array}$ & $\begin{array}{l}\text { tertia } \\
\text { ry } \\
\text { indus } \\
\text { try }\end{array}$ & $\begin{array}{l}\text { prima } \\
\text { ry } \\
\text { indus } \\
\text { try }\end{array}$ & $\begin{array}{l}\text { Second } \\
\text { ary } \\
\text { industry }\end{array}$ & $\begin{array}{l}\text { tertiary } \\
\text { industry }\end{array}$ & $\begin{array}{l}\text { primary } \\
\text { industry }\end{array}$ & $\begin{array}{l}\text { Second } \\
\text { ary } \\
\text { industry }\end{array}$ & $\begin{array}{l}\text { tertia } \\
\text { ry } \\
\text { indus } \\
\text { try }\end{array}$ & $\begin{array}{l}\text { primary } \\
\text { industry }\end{array}$ & $\begin{array}{l}\text { Second } \\
\text { ary } \\
\text { industry }\end{array}$ & $\begin{array}{l}\text { tertiary } \\
\text { industry }\end{array}$ \\
\hline \multirow{4}{*}{$\begin{array}{l}9 \\
0 \\
- \\
- \\
9 \\
5\end{array}$} & $\mathrm{Nij}$ & 69.96 & 205.72 & $\begin{array}{c}136.0 \\
7 \\
\end{array}$ & 57.48 & 169.03 & 111.80 & 27.87 & 81.95 & 54.20 & 12.56 & 36.94 & 24.43 \\
\hline & Pij & $\begin{array}{c}- \\
15.97 \\
\end{array}$ & 28.89 & 2.35 & 7.33 & -0.16 & -13.33 & 12.62 & 1.01 & 24.16 & 11.38 & -16.82 & -5.19 \\
\hline & Dij & 24.99 & -23.63 & 30.79 & 14.09 & 25.54 & 19.65 & 14.77 & 22.26 & 89.15 & 0.07 & 16.78 & 11.96 \\
\hline & Gij & 78.97 & 210.99 & $\begin{array}{c}169.2 \\
1\end{array}$ & 78.90 & 194.42 & 118.13 & 55.26 & 105.22 & $\begin{array}{c}119.2 \\
0\end{array}$ & 24.01 & 36.90 & 31.20 \\
\hline \multirow{4}{*}{$\begin{array}{l}9 \\
5 \\
- \\
- \\
0 \\
0\end{array}$} & $\mathrm{Nij}$ & 32.95 & 230.57 & $\begin{array}{c}167.8 \\
9\end{array}$ & 28.14 & 196.96 & 143.42 & 16.64 & 116.45 & 84.80 & 5.97 & 41.79 & 30.43 \\
\hline & Pij & -4.16 & -4.52 & 18.36 & 4.56 & 0.24 & -15.04 & 6.74 & -11.90 & -9.00 & 4.64 & -13.61 & -0.34 \\
\hline & Dij & -0.54 & 35.42 & 76.13 & 26.75 & 8.98 & 4.49 & -19.77 & 50.53 & 5.79 & -0.60 & 25.13 & 10.42 \\
\hline & Gij & 28.25 & 261.47 & $\begin{array}{c}262.3 \\
8\end{array}$ & 5.95 & 206.18 & 132.86 & 3.61 & 155.08 & 81.58 & 10.01 & 53.31 & 40.52 \\
\hline \multirow{4}{*}{$\begin{array}{l}0 \\
0 \\
- \\
- \\
0 \\
5\end{array}$} & $\mathrm{Nij}$ & 94.20 & 923.59 & $\begin{array}{c}436.6 \\
3\end{array}$ & 69.55 & 681.96 & 322.40 & 43.13 & 422.87 & $\begin{array}{c}199.9 \\
1\end{array}$ & 16.57 & 162.44 & 76.79 \\
\hline & Pij & 21.00 & -61.78 & 84.39 & -2.28 & 36.77 & -20.30 & 2.08 & 21.21 & $\begin{array}{c}- \\
18.60 \\
\end{array}$ & 9.95 & -35.43 & 3.88 \\
\hline & Dij & $\begin{array}{c}- \\
45.97 \\
\end{array}$ & -22.26 & 88.02 & -3.33 & 15.42 & 33.87 & -22.98 & -4.54 & $\begin{array}{c}- \\
19.20 \\
\end{array}$ & -5.05 & -5.90 & -4.28 \\
\hline & Gij & 27.23 & 839.55 & $\begin{array}{c}609.0 \\
4 \\
\end{array}$ & 63.94 & 734.15 & 335.97 & 22.23 & 439.55 & $\begin{array}{c}162.1 \\
2 \\
\end{array}$ & 21.46 & 121.10 & 76.39 \\
\hline \multirow{4}{*}{$\begin{array}{l}0 \\
5 \\
- \\
- \\
0 \\
8\end{array}$} & $\mathrm{Nij}$ & $\begin{array}{c}156.4 \\
8 \\
\end{array}$ & $\begin{array}{c}1029.8 \\
2 \\
\end{array}$ & $\begin{array}{c}641.5 \\
8 \\
\end{array}$ & $\begin{array}{c}116.8 \\
1 \\
\end{array}$ & 768.77 & 478.95 & 67.90 & 446.86 & $\begin{array}{c}278.3 \\
9 \\
\end{array}$ & 24.76 & 162.93 & 101.50 \\
\hline & Pij & $\begin{array}{c}- \\
57.06 \\
\end{array}$ & -100.59 & $\begin{array}{c}187.4 \\
1 \\
\end{array}$ & -8.94 & 28.53 & -19.84 & -7.62 & 35.92 & $\begin{array}{c}- \\
29.80 \\
\end{array}$ & 13.96 & -27.02 & 11.50 \\
\hline & Dij & $\begin{array}{c}- \\
85.54 \\
\end{array}$ & -77.61 & 5.49 & $\begin{array}{c}- \\
28.09 \\
\end{array}$ & 92.34 & -12.91 & -40.68 & -110.74 & $\begin{array}{c}- \\
28.35 \\
\end{array}$ & -16.27 & 95.45 & 4.35 \\
\hline & Gij & 13.88 & 851.62 & $\begin{array}{c}834.4 \\
8\end{array}$ & 79.78 & 889.64 & 446.19 & 19.59 & 372.04 & $\begin{array}{c}220.2 \\
5\end{array}$ & 22.45 & 231.36 & 117.35 \\
\hline \multirow{4}{*}{$\begin{array}{l}9 \\
0 \\
- \\
- \\
0 \\
8\end{array}$} & $\mathrm{Nij}$ & $\begin{array}{c}308.3 \\
1 \\
\end{array}$ & $\begin{array}{c}2041.4 \\
7 \\
\end{array}$ & $\begin{array}{c}1186 . \\
32 \\
\end{array}$ & $\begin{array}{c}253.3 \\
2 \\
\end{array}$ & $\begin{array}{c}1677.3 \\
8 \\
\end{array}$ & 974.74 & 122.82 & 813.23 & $\begin{array}{c}472.5 \\
8 \\
\end{array}$ & 55.36 & 366.58 & 213.02 \\
\hline & Pij & $\begin{array}{c}- \\
70.38\end{array}$ & 286.69 & 20.50 & 32.30 & -1.57 & -116.19 & 55.63 & 10.04 & $\begin{array}{c}210.5 \\
9\end{array}$ & 50.15 & -166.93 & -45.28 \\
\hline & Dij & 69.70 & -139.83 & $\begin{array}{c}683.9 \\
4 \\
\end{array}$ & $\begin{array}{c}- \\
50.85 \\
\end{array}$ & 353.15 & 193.22 & -52.04 & 231.74 & $\begin{array}{c}515.2 \\
5 \\
\end{array}$ & -21.09 & 390.45 & 121.06 \\
\hline & Gij & $\begin{array}{c}168.2 \\
3 \\
\end{array}$ & $\begin{array}{c}2188.3 \\
3 \\
\end{array}$ & $\begin{array}{c}1890 . \\
76\end{array}$ & $\begin{array}{c}234.7 \\
7 \\
\end{array}$ & $\begin{array}{c}2028.9 \\
6 \\
\end{array}$ & $\begin{array}{c}1051.7 \\
7 \\
\end{array}$ & 126.41 & $\begin{array}{c}1055.0 \\
2 \\
\end{array}$ & $\begin{array}{c}777.2 \\
3 \\
\end{array}$ & 84.42 & 590.10 & 288.80 \\
\hline
\end{tabular}

Source: China city statistical yearbook, 1991-2009

Secondly, applying the high-technology and advanced applicable technology to transform traditional industries, taking the industry of Electronic and electrical, machinery and equipment manufacturing, petroleum and chemical as the strategic advantage ones, to cultivate, and improve industrial competitiveness. Moreover, with the guidance of the scientific concept of development, accelerating the development of the second and the third industry, intensifying foreign investments, and developing modern industry, to realize the combination of economic development and environmental protection.

Thirdly, to vigorously develop the tertiary industry, speed up the pace of industrial structure adjustment, financial insurance, intermediary services, modern logistics, and other currently emerging service industry as education, real estate, tourism, community service, and etc.

To sum up, only by adjusting and optimizing the industrial structure, can one narrow the gap between regional economic growths, and promote the regional economy development coordinately and rapidly. 


\section{References}

[1] Cuigonghao, weiqingquan, chenzongxing.Regional Analysis and Planning[M], Beijing: Higher Education Press, 1999.(in Chinese)

[2] Yangxuanliu, Analysis on the Effectiveness of industry structure in economic growth of Shaannxi Province[J],Statistics and Information Forum, 2008. (in Chinese)

[3] Yusuhui, Analysis on the Effectiveness of industry structure in economic growth[J], Social sciences review ,2002. (in Chinese)

[4] China city statistical yearbook,1991/ State statistics bureau city social economic investigation department $[\mathrm{M}]$, China statistical publishing press, 1992. (in Chinese)

[5] China city statistical yearbook,1996/ State statistics bureau city social economic investigation department [M], China statistical publishing press, 1997. (in Chinese)

[6] China city statistical yearbook,2001/ State statistics bureau city social economic investigation department[M], China statistical publishing press, 2002. (in Chinese)

[7] China city statistical yearbook,2006/ State statistics bureau city social economic investigation department[M], China statistical publishing press, 2007. (in Chinese)

[8] China city statistical yearbook,2009/ State statistics bureau city social economic investigation department $[\mathrm{M}]$, China statistical publishing press, 2010. (in Chinese)

[9] Zhuzhiming, libaihan, chendigui, the situation, the key and requirements of Shandong economic structure adjustment[J], Jinan financial, 2003. (in Chinese)

[10]Wei Wei etc, Analysis of Comparative Advantage of Chinese Regional Economy[M], Beijing: Chinese Economic Press, Jun. 1996.(in Chinese)

[11]Sun Nengli, Huangwenqing, Qu Xiang, Zhang Junbiao, Agricultural Structure in western China by Comparing with before and after CFFG Based on Shift-Share Method[M]. Chinese of population, resources and environment, 2009.

This work is partially supported by plan 863 (2006AA01A126) 